\title{
Sciendo
}

\section{Ukraine a country in crisis between Europe, Russia, and a complex electoral process.}

\author{
Alessandro Figus \\ International Institute of Management IMI-Nova, (Moldova) \\ Email:a.figus@unilink.it \\ Alessandra Alberti \\ Link Campus University, (Italy) \\ Email: \\ Ludovico de Serio \\ M. Kozybayev North Kazakhstan State University, (Kazakhstan) \\ Email:ludovico.deserio@gmail.com
}

Doi: $10.2478 /$ gssfj-2020-0007

\begin{abstract}
To this day, Ukraine is still experiencing difficult times both economically and politically. The economic and political crisis at the end of 2014, which led to the dismissal of President Yanukovich, meant that the territory of Crimea and, therefore, the port of Sevastopol as well, remained under Russian control. The new elections of 2019 carried a breath of fresh air and hope also for new relationships with Russia. The paper wants to photograph this situation and analyse the recent 2019 presidential elections.
\end{abstract}

Keywords: Ukraine, elections, political and economic system.

\section{The history of Ukraine}

Following the collapse of the Soviet Union, Ukraine became an independent state on the 24th of August 1991. Ukraine's history has always been linked to that of Russia. It was the cradle of the Slavs, that over time settled in the Russian, Danubian and Balkan, Germanic, and Siberian regions. It is worth remembering that in 1654, with the Treaty of Perejaslavl, Ukraine was indeed submitted to the protection of Tsar Alexis of Russia and broke all oaths to the King of Poland (which for Ukrainian nationalists always represented the end of Ukraine's independence and the beginning of its darkest years, with the imposition of the name "Little Russia" over that of Ukraine, in use in the 16th century). The peace of Andrusovo (1667) assigned to Poland the Ukrainian regions west of Dnjepr and to Russia those in the east. Catherine II started a new historical phase, which led to the conquest of Crimea (1784) and transformed Ukraine into a province, eliminating the Hetmans. After the parting of Poland, Austria took over Galicia, while Russia took over Poland 
and Volinia. In this way, a large part of Ukraine became part of the empire, with a policy of demographic and cultural Russification.

After 1850, Odesa became a large port and Ukraine experienced its first industrialization, with strong economic growth and, consequently, a cultural revival, reawakening nationalism, promptly repressed by the tsarist authorities. The Ukrainian language was banned in 1874 and wrongly defined as a Russian dialect. After the revolution of October 1917, Ukrainian separatist tendencies grew stronger. The German and Austro-Hungarian armies occupied Ukraine and forced the newly formed Russian Bolshevik government to establish the Assembly Republic in Kyiv. Following the separate peace of Brest-Litovsk with the Central Empires (March 3, 1918), Ukraine was finally granted its independence ${ }^{29}$.

At the end of the Great War, the Ukrainian leadership was taken by the Hetman Petliura, who, in favour of the agreement, wanted to achieve a "great independent Ukraine" thanks to it. After several battles with the Bolsheviks, the "whites", almost all the lands of Ukraine were reunited (1922) in the Soviet Republic of Ukraine, while other areas of the region were assigned to neighbouring nations. In 1923, Ukraine thus became an integral part of the USSR, undergoing a profound denationalization (1924-29), as well as the mass repression of peasants trying to rebel against collectivization.

During the Second World War, following the Germanic offensive, the country was subjected to the German administration (1941-43). With the Russian counter-offensives, Ukraine suffered an immense loss of population and enormous economic damage. There were also further episodes of savage violence, following the clash between partisan formations and armed groups, which placed themselves at the service of the German occupier, in the hope of obtaining autonomy. Ukraine was forced to pay a high price, accused of high treason by Stalin, and subjected to brutal repression, especially against the Jews that were living in the State. At the end of the war, the USSR added to the original Ukrainian territory, under its sovereignty, the former Polish Ukraine, Bukovina, Bessarabia, and sub-Carpathian Russia. Within the

\footnotetext{
${ }^{29}$ The acknowledgement of full independence for Ukraine took place despite the fact that on the 4th January 1918 France recognized de facto the Ukrainian Verkhovna Rada in order to prevent a recognition by Germany which took place with the so-called Bread Peace in February of the same year. It was however the peace of Brest Litovsk, even though it appeared as a gigantic diplomatic bluff, that decreed complete and legitimate autonomy. Italy was ensuring that the European balance would not be disrupted, while the United States of America did not want a Russia excessively weak, as it would no longer oppose the Japanese power in the East. In this framework, the role of Ukraine became fundamental from the strategic point of view, driving the Germans away from the Black Sea. (vedi Petracchi G. 1982, La Russia rivoluzionaria nella politica italiana 1917/25, Laterza, Roma-Bari, 1982, pp.43-55).
} 
country, the central and regional governments took vigorous measures, both to rebuild what had been destroyed and to strike at the collaborationists. Ukraine, although still part of the USSR, was admitted to the U.N. as a separate national entity and was granted access to the highest Soviet central offices, to the extent that a Ukrainian, Nikita Khrushchev, rose to power, integrating the country into the Soviet system (1945-51). His successor, Leonid Brezhnev, was more cautious, especially towards the nationalist feelings of the individual republics. Vladimir Shcherbytsky, of strict "Brezhnevian" observance, ruled Ukraine with an iron fist, from 1973 to 1989 , sending anyone who dared to raise a critical voice to labour camps or mental hospitals. Unlike that of Russia, the clandestine opposition did not arise among intellectuals but among workers, especially miners, and grew into the Ukrainian People's Movement for Restructuring (Rukh). With the advent of Gorbachev, the general political situation suddenly changed and the nationalist movement reappeared. Both Gorbachev and Yeltsin had already resigned themselves to the possible separation of the Baltic states, but they could not accept Ukrainian independence.

When the situation seemed to collapse, Leonid Kravchuk urged the Parliament to pass a law for the creation of a Ukrainian army (400,000 units strong), for the combined control of Soviet nuclear weapons on Ukrainian soil and the Soviet fleet in the Ukrainian Black Sea ports (based in Sevastopol, Crimea). In addition to these problems, there was a difficult situation in Crimea $(27,000$ sq. $\mathrm{km}$, little more than 2.5 million inhabitants, mostly Russians), the cause of another dilemma. The region had always been Russian territory but, in the euphoria of the 1954 festivities, to celebrate 300 years of friendship between the two peoples, the Russians, gave the region to Ukraine as a gift but still as an autonomous Republic, even if the cession had been granted first by the Russian Federation and, later, by the USSR Parliament. However, on January 23, 1992, the Russian Parliament asked for its revision and Russia demanded its revocation. Ukraine opposed to its return.

The situation was about to deteriorate, there were rumors of an imminent Russian attack, when Yeltsin and Kravchuk, elected President of the Ukrainian Republic in December 1991, reached a compromise, averting confrontation. After the proclamation of Ukrainian independence on 24 August 1991, confirmed by a referendum on the following 1 December, separatist pressures in Crimea had grown, partly fostered by Moscow, which was in favour of its integration into the Russian Federation. In May 1992, the Crimea declared its independence (118 votes in favour and 28 against, pending a popular referendum), a declaration was withdrawn in exchange for autonomous concessions, including cultural and administrative ones, which did not, however, suppress the desire to follow its independent path from Ukraine. In May 1992, the Crimea declared independence (118 votes in favour and 28 against, pending a popular referendum), a declaration withdrawn in 
exchange for autonomous concessions, including cultural and administrative ones, which did not, however, suppress the desire to follow its independent path from Ukraine. On 31 May 1995, the central government rejected the secessionist project and the Russian Federation recognized its legitimate belonging to Ukraine.

The problem of Crimea is part of a much wider one, involving all the former Soviet republics, where collective interests have always imposed themselves on individual rights. The Russification policy mobilized many people within the Soviet Union, altering fragile balances. If we consider the current Community of Independent States (CIS), we can see that more than 60 million people live outside their own nations, and, out of these, 25 million are Russians. Today, considering new events that have led to direct control by Russia, the problem is more topical than ever.

During the legislative elections (1994, 1998 and 2001) the left-wing and former communist parties, which were to lead to the presidency of the Republic Leonid Kuchma in both 1994 and 1999 established their position. Thus the country found itself deeply divided between the nationalist west and the pro-Russian east. The search for a solution to the question of partitioning the Russian Black Sea fleet was started in 1995, but the issue concerning Crimea is still open. In 1996, a new Constitution came into force, replacing the Soviet Constitution of 1978, amended several times, which was established the presidential form of government. President Leonid Kuchma, reinforced by his power, seemed to be concerned about reintroducing the country into a regional economic set with good perspectives, trying to avoid the problems of social nature, which had arisen in 1996, following the strikes of the miners. The year 1997 also marked the attempt by Ukraine, together with Russia, to find a solution to the problem of Transnistria, a territory belonging to the Republic of Moldova. With the presence of the President of the Republic Leonid Kuchma, in Moscow was signed a memorandum, based on which the two countries attempted to normalize the relations between Moldova and Transnistria (or Dniestrovnia, in Russian). The Odesa Agreement of 20 March 1998 represented an attempt to make a further effort, both to develop contacts between Moldova and Transnistria and to find a definitive solution to the problem, which directly involved Ukraine, being the only neighbouring country.

On the 26 of February, Bill Clinton delivered a speech in San Francisco in which he strongly supported NATO enlargement, claiming that it was necessary to keep NATO's doors open to new democratic countries, encouraging them to strengthen their democracy. Clinton introduced the idea of a partnership between NATO and Ukraine, which was confirmed at the 
summit in April of the same year ${ }^{30}$. Bill Clinton developed a policy that showed the blatant tug-of-war that was taking place between the European Union and the USA, both of which were keen to enlarge Western influence on the East. On one side, NATO, to be considered American-led, and, on the other, the European Union, which favoured above all Berlin, once again barycentric over a consolidating Europe. In this context, Ukraine could play an interesting geopolitical role in the years to come, once it manages to disengage definitively from Moscow's influence, but this will be difficult, as the problem is not only political but also economic. On the economic side, Ukraine has tried to gain independence from Russia, but most of the energy is imported from there, especially after the Chernobyl tragedy.

The European Union strongly supported the candidate president Viktor Yushchenko in 2005. The strong protest of the supporters of this candidate forced the Parliament to examine major changes in the Basic Law. The assembly gave the floor for a series of amendments to the law regarding the election of the president, clearing the way for the presidential ballot on 26 December. Taking note of the new environmental conditions, the opposition, led by Viktor Yushchenko, decided to suspend the protests on the square in the centre of Kyiv. The run-off between Yushchenko and pro-Russian Prime Minister Viktor Yanukovich resulted in his victory in the second run-off of the presidential elections. With the repeated runoff (which is quite unusual, not only for Ukraine) and the election of a pro-Western and pro-European president such as Viktor Yushchenko, the axis of politics unexpectedly shifted towards Western Europe.

In any case, I still share Jean's opinion ${ }^{31}$ about Russia when he states that things have changed since 11 September and Putin, who moved very skilfully pursuing the Russian national interest, strongly supported the United States. The fight against terrorism unites Westerners with Russians and Ukrainians (also because of obvious ties of a religious nature), at the same time bringing

30 Declaration of the Nato-Ukraine Commission Summit, del 24 aprile1999. Summit held in Washington on 24 April between the government representatives of the 19 NATO countries and those of Ukraine, which underlined "the common desire to see Ukraine take greater advantage of the opportunities offered by participation in the Partnership for Peace Programme", promoted by NATO to strengthen ties with the Eastern candidates for future membership of the Alliance. (v. Dinucci M., La Nato in marcia verso Est, in Liberazione dell'11 maggio 1999). In spite of the existence of this "distinctive partnership" with Ukraine, NATO increasingly favours relations with Russia, as shown by the 20 NATO-Russia Council, which involves Russia directly and forgets Ukraine, reduced to being involved only in naval exercises on the Black Sea.

${ }^{31}$ See Jean C., 11 settembre attacco alla Russia, in Limes 1-2002, pp. 131-136. 
Europe closer to America and leading Europe to rediscover strong ties in the East.

Finally, it is necessary to underline how much the Tymoshenko issue has weighed on Ukraine's international balance, including its strong proximity to the European Union and the creation of a strong bridge between East and West. The matter is whether the European Union and Ukraine, having implemented the Association Agreement, will be able to boost the circulation of goods and people between the two countries and encourage deeper integration which de facto has been stalled by the political crisis.

It was thought that with Yushchenko democracy in the country would grow, as well as the freedom of the media, finally able to express themselves freely following the revolution, but not even Yushchenko was ever able to heal the internal and external divisions, which made negotiations with the EU and NATO complicated.

Even today, Ukraine is still going through difficult times. It will take time to completely rebalance the country, given that it is a country consisting of a set of ethnic groups and nationalities, which need to co-exist and live in harmony. Often, however, it is difficult to avoid those actions that lead to a further deepening of the crisis. The only possibility remains that of pursuing, by all means, the path of dialogue. It is not acceptable, all of a sudden, to return to the Cold War. The crisis in Ukraine is, undoubtedly, the lowest point in the relations between Russia and the West and with the European Union.

Euromaidan's protests, created to demonstrate against the Ukrainian executive's decision not to sign the association agreement with Brussels, ended up overwhelming the Kyiv government and the Yanukovych presidency, forcing him to flee to Russia in February 2014. Four months of demonstrations radically changed the course of events in the former Soviet country and removed the entire political class unable to look to the West from the power. New people were needed to lead the nation through very difficult times. Among them was Poroshenko. Ukraine's most popular chocolate entrepreneur-politician did not want to shut the door to Russia, and in 2014 he rose to power. During the five years of his presidency, Poroshenko pursued policies with divergent developments in Ukraine, making it difficult to judge his political actions. He has experienced very difficult political times. The outbreak of the war in the Donbas and its bloody prosecution, the economic crisis experienced by Kyiv because of the consequences of the conflict, the difficult relationship with Moscow, which is just a few years has gone from being Ukraine's main strategic partner to rival, and the issue of Crimea, annexed to the Russian Federation in February 2014, are just some of the events that occurred during Poroshenko's presidency. Moreover, the president's militaristic and aggressive approach did not solve the Donbas conflict at its root. During his mandate, Ukraine has attempted to be more European than Soviet and the country's own culture has opened to external 
influences. A period of epochal change that is bound to have an enduring impact on the future of the nation. The signing of the Association Agreement between Brussels and Kyiv in 2014 and its implementation in 2017, marked the achievement of an important goal and the confirmation of a decisive change for Ukrainian foreign policy. The citizens of the country have also been able to experience, from 2017, the possibility to freely move within the Schengen area without requiring a visa. A historic turning point that has led and continues to lead to a real cultural revolution in and around Kyiv, as well as a further success for national diplomacy.

Nevertheless, in terms of the fight against corruption, the reform of the judicial system and the status of the economy have been those weaknesses of the Poroshenko administration that ultimately led to its defeat in the presidential elections in 2019 and then The relationship with the Russian Federation, which was bad for the entire duration of the presidential term, affected the stability of Kyiv and brought the country to the brink of military confrontation with its powerful neighbour.

A period of epochal change that is bound to have an enduring impact on the future of the nation. The signing of the Association Agreement between Brussels and Kyiv in 2014 and its implementation in 2017, marked the achievement of an important goal and the confirmation of a decisive change for Ukrainian foreign policy. The citizens of the country have also been able to experience, from 2017, the possibility to freely move within the Schengen area without requiring a visa. A historic turning point that has led and continues to lead to a real cultural revolution in and around Kyiv, as well as a further success for national diplomacy.

Nevertheless, on the side of the fight against corruption, the reform of the judicial system and the status of the economy have been the weaknesses of the Poroshenko administration, which ultimately led to its defeat in the presidential elections in 2019. The relationship with the Russian Federation as well as negative for the entire duration of the presidential term, affecting the stability of Kyiv and pushing the country to the verge of military confrontation with its powerful neighbour.

\section{2019 Ukrainian election: from Poroshenko to Zelensky}

Poroshenko, with an absolute majority of votes in the first round (55.46\%) triumphed on the former Prime Minister Julija Tymoshenko in the 2014 Presidential elections which for the first time did not involve the participation of the self-proclaimed pro-Russian authorities occupying the Donetsk People's Republic, of the People's Republic of Lugansk and Crimea. The oligarch Petro Poroshenko, former Minister of Foreign Affairs and the Economy both in Western and pro-Russian governments established himself as a compromise figure by settling in the presidency without festive 
ceremonies. In a country where the separatist uprising in the East were threatening the unity of the nation, he immediately showed himself determined to bring Ukraine closer to Europe and pursue a firm strategy against the Eastern separatists, confirming his intentions to open a dialogue with Moscow.

In 2014, he signed a milestone in the history of Ukraine's international relations: the Association Agreement with the EU - a partnership that guarantees cooperation and convergence on economic policy, legislation and regulation in a wide range of sectors, among which equal rights for workers, free movement of people, information exchange in the justice sector, modernization of Ukraine's energy infrastructure and access to the European Central Bank for investment. On one hand, with this Agreement, the EU wanted to make sure that its main imports and exports from and to Ukraine -wheat and natural gas- where not endangered were not threatened by the turmoils taking place in the country and the possible consequent economic reforms in the country aimed at limiting these aspects; At the same time, Ukraine intended to intensify its own exports by participating in free trade agreements with the European Union as well as encouraging investment from abroad.

If Germany and the United Kingdom welcomed this agreement with a good attitude, Russia declared that it would impose "protectionist measures" on Ukraine after the implementation of the agreement with the EU. Putin concluded that the agreement with the EU, as had happened with the old USSR satellites, would precede entry into NATO and expressed his opposition by taking a region that had been Ukrainian since 1954, namely the Crimea, where there was a majority of Russian people. Sergio Romano suggested at ISPI that since then there has been a sort of parallelism between the American policy towards Russia and the one of Russia towards Ukraine. The United States, after the annexation of Ukraine, imposed economic sanctions on Russia in the hope of arousing civil society's mood against Putin's regime; while Russia, from its part, did the same by putting obstacles in the way of Ukrainian ships crossing the Kerch Strait to reach the two Ukrainian ports on the western shores of the Azov Sea. In fact, after the loss of Sevastopol, Mariupol and Berdyansk have become the maritime ports of a country that has long been a precious granary for the countries bordering the Black Sea and the Mediterranean ${ }^{32}$.

On one side, Petro Poroshenko has brought Ukraine closer to the EU and NATO, on the other, in the eyes of many Ukrainians he has betrayed the hopes of the political renewal promise that animated the Euromaidan revolution, including above all the fight against corruption - a problem deeply felt by Ukrainian society. Ukraine continues to occupy a very low position

${ }^{32}$ Romano, S. (27/12/2017) “Russia-Ucraina: verso l'escalation?” ISPI. 
in the Corruption Perception Index 2018 (CPI) published by Transparency International ${ }^{33}$. It ranked 120 th out of 180 countries in $2018: 10$ positions more than in 2017, but still the worst result in the whole region after Russia.

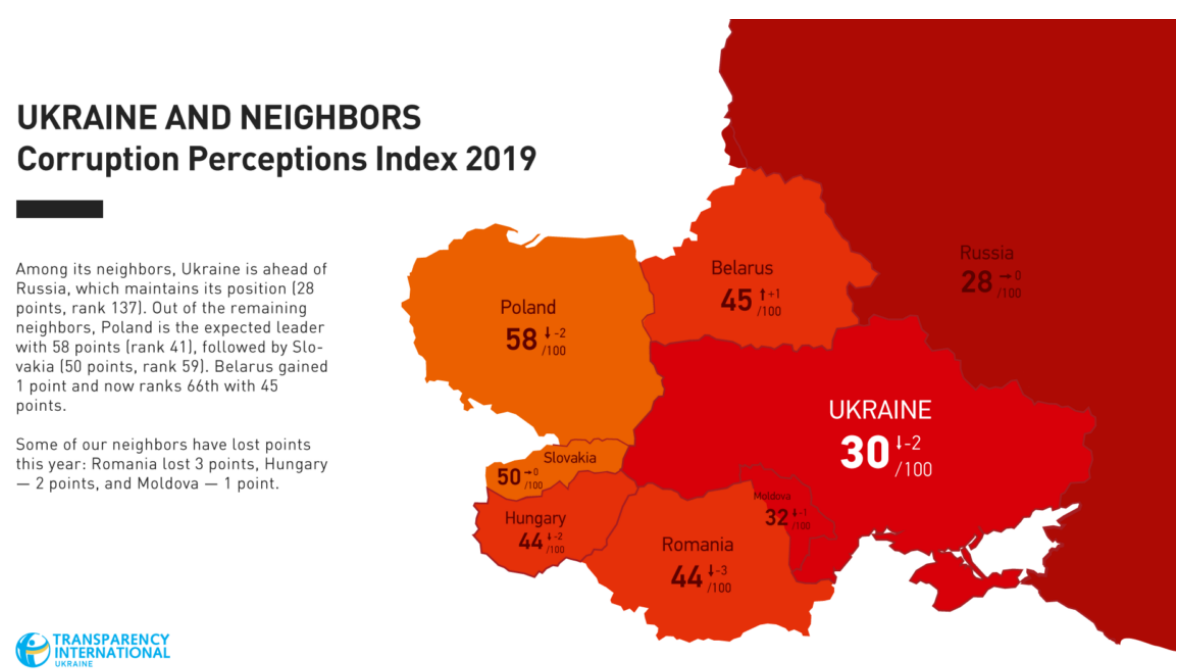

Figure 1. Source: Corruption perceptions in Ukraine and Neighbors

So, during his term of almost five years, Poroshenko did not dismantle the corrupt government system of Ukraine, nor did it significantly affect the oligarchic system of which he is part. The former President has also been accused of failing in creating and protecting free press, in a country where many media are still held hostage by the interests of some oligarchs.

The country's economic problems have helped fuel the population's discontent with rampant corruption. As we can see from the table below published by the International Monetary Fund, Ukraine's per capita GDP stood at $\$ 2,964$ in 2018. A condition that makes Ukraine the poorest country in Europe, followed by Moldova $(\$ 3,226)$, Belarus $(\$ 6,020)$, and Russia (\$ 10,950).

\begin{tabular}{|l|c|c|c|c|c|}
\hline & $\mathbf{2 0 1 7}$ & $\mathbf{2 0 1 8}$ & $\mathbf{2 0 1 9}$ & $\mathbf{2 0 2 0}$ (forecast) & $\mathbf{2 0 2 1}$ (forecast) \\
\hline GDP (current prices in \$) & 114.05 .00 & 134.03 .00 & 148.47 .00 & 149.50 .00 & 169.47 .00 \\
\hline $\begin{array}{l}\text { GDP per capita } \\
\text { (current prices in \$) }\end{array}$ & $2,655.939$ & $2,963.465$ & $3,220.931$ & $3,528.331$ & $3,865.466$ \\
\hline Population & 45.37 .00 & 42.47 .00 & 55.38 .00 & 52.51 .00 & 50.04 .00 \\
\hline
\end{tabular}

\footnotetext{
${ }^{33}$ Ukraine in CPI 2018: Second Worst Score of All Neighbors After Russia, Трансперенсі Інтернешнл Україна
} 
Poroshenko also failed in keeping the difficult promise of solving or improving the situation in the eastern region of Donbas. The war is still a dramatic reality for Ukraine. According to OSCE data ${ }^{34}$, since the beginning of the war, there have been over 13,000 victims and 30,000 injured. The four countries of the so-called "Normandy Format" (which includes the negotiators designated by Russia, Ukraine, France, and Germany) have not met at a high level since October 2016 and the Minsk agreements are not respected, with almost daily violations of the cease-fire: the Special Monitoring Mission (SMM) of the Organization for Security and Cooperation in Europe (OSCE) has detected over 270,000 violations of the ceasefire in 2018. The situation has reached the first direct military clash in November $2018^{35}$ when in the Kerch Strait Russia attacked three Ukrainian military ships, arresting 24 sailors still detained in Russia. Poroshenko's strategy towards Russia was to continue and raise the level of the clash: not by chance, Poroshenko's slogan ("Army! Language! Faith!") insisted on the modernization of the army, the promotion of the Ukrainian language (at the expense of the Russian) and on the autonomy of the Ukrainian Orthodox Church from the one of Russia; one of the few achievements obtained last October.

Last act of the Poroshenko's presidency: the law on language. But let's make a digression on this topic. Article 10 of the Ukrainian Constitution, in force since 1996, states that Ukrainian is the only official language of the country; at the same time, it guarantees the development, protection, and freedom of use of Russian and other national minority languages. As already mentioned, in 2012, however, the Yanukovič government introduced the concept of "regional language" for areas (regions or cities) where a minority of more than $10 \%$ of residents spoke a language other than Ukrainian. According to this provision, in these territories, the regional language achieved the status of Ukrainian and could be used as a vehicular language in schools and local administrative bodies. Russian was consequently recognized as a "regional language" in the regions of Donetsk, Luhansk, Kharkiv, Zaporižžja, Cherson, Mykolaï, Dnipro, Odesa, in the Crimea and some cities. The law signed by President Janukovič was immediately strongly criticized both by internal opposition to the country and by European bodies such as the Venice Commission. Questioned especially in the aftermath of Euromaidan in 2014, this legislation in 2018 was decreed unconstitutional by the Ukrainian Constitutional Court. Precisely for this reason, the bill passed this April was introduced to the Rada. A law that erases the concept of "regional language" and elevates the Ukrainian to a single language allowed in the public sphere, as well as a symbol of the state, whose offense can also be punished by arrest.

\footnotetext{
34 OSCE/ODIHR Election Observation Mission Final Report (2005), OSCE report result 35 Ambrosetti, E. (07/12/2017) "Tensione Russia-Ucraina: cause e conseguenze dell'incidente di Kerch", ISPI
} 
Petro Poroshenko completed his Presidential term by putting his signature on an important law discussed on May 15th ${ }^{36}$ : the law on language (law No. 5670$\mathrm{d}^{37}$ ), definitively approved on April 25th with 278 favourable votes out of 450 . Over 2000 changes and reworkings were made to convince most of the deputies to pass the bill, approved in a first reading on October 4th last year. The new law removes the minority languages - including Russian (although never mentioned in the document, as opposed to English, which has been nominated 18 times) - while also changing the status of regional languages, drastically limits their use in the public sphere. Andrij Parubij, the spokesman for the Rada, called the law a matter of national security for the country. Poroshenko, once defeated in the Presidential election, had promised the Ukrainians that he would have still signed this law on language as soon as Rada had approved it. The language, along with faith and the army, was one of the three pillars on which Poroshenko had founded his electoral campaign. According to the former President, this law was necessary and "historic" for Ukraine $^{38}$.

In the world of education, from 2023 the Ukrainian will be the mandatory vehicular language for all schools starting from the fifth grade (corresponding to the fourth grade in the Italian system). Minority languages are allowed in kindergartens and primary schools, as well as being taught as disciplines within the school curriculum. As for universities, some subjects can be taught in English and other official EU languages (not in Russian). The school issue is indeed central in a country where, out of 3.8 million children and school-age children, nearly 400,000 are enrolled in institutions where the vehicular language is not Ukrainian. According to 2017 data, there are 580 state schools in Russian (eight in Kyiv only), around seventy in Romanian and Hungarian. The problems for these students are very practical and arise above all at the end of the course of studies when there is a lack of knowledge of the official language useful in university or work placement. In the state exam, for example, in 2017 three quarters of the Hungary-phonic boys from the Berehove region were found to be insufficient in the Ukrainian test, emphasized Education Minister Lilija Hrynevyč.

\footnotetext{
${ }^{36}$ See: Draft Law on Ensuring the Functioning of the Ukrainian Language as State language. http://search.ligazakon.ua

${ }^{37}$ See: Law of Ukraine on ensuring the functioning of the Ukrainian language as a state language. https://zakon.rada.gov.ua/
}

38 See: "Poroshenko called the Rada's decision to adopt a law on the RBC language a historic one”, RBK, 25.04.2019. www.rbc.ru 
In addition to school, radio and television will have to broadcast $90 \%$ in the Ukrainian language from 7 to 22. An exception is the transmission of events intended for a European public, as in the case of Eurovision. Also, newspapers in languages other than Ukrainian will have to publish a similar edition in Ukrainian. At newsstands and bookshops, at least $50 \%$ of the editorial material on sale will have to be in Ukrainian (stores specializing in newspapers and foreign books are excluded). These new measures will put different media (newspapers with medium-low circulation) in great difficulty and not so much in front of their public but related to the limited economic capacities. It seems equally questionable that the launch of an equal edition in the Ukrainian language could increase the number of sales to come to fill the relative costs of translation and printing. On the internet, the websites with the ".ua" domain will have to bring the Ukrainian version as the first interface page. The programs and software must be in Ukrainian, English, or other official EU language. Even $90 \%$ of films in theatres will have to be in the Ukrainian language (the remaining 10\% will have to bring in any case Ukrainian subtitles and the same goes for theatrical performances). For singers, it will be possible to perform in another language. Event posters and flyers will always have to contain the Ukrainian language; in the case of multiple languages, the Ukrainian translation must be reported in a size of a character equal to or greater than that of the other languages. Furthermore, in Russian-speaking materials circulating in Ukraine, toponymy is also subject to change: the denominations of the places will not be translated into Russian but transliterated by the Ukrainian. Therefore, it will no longer be permissible to write in Russian Kiev (Киев) but Kyjiv (Кыйив), not Khar'kov (арьков) but Kharkiv (аркив).

Overall, the package of measures launched by the Rada and signed by the former head of state Poroshenko tries to fill a defect in the definition of the national state language, but also put several players in the Ukrainian cultural and information sphere in difficulty and this can damage the rights of minorities. This law wants, to sum up, systematize and deepen a "linguistic path" that Porošenko has undertaken over the years.

This is a process that has often sparked opposing nationalisms, spreading the questionable belief that there is an automatic correlation between the spoken language and the speaker's political identity.

It is not a coincidence that the new President Zelensky, a Russian speaker, has criticized this legislation. The TV series that made him famous, "The servant of the people", is in Russian, and in the round of elections following the first one, the regions characterized by profound Russophony supported him. Furthermore, among the few points in Zelensky's electoral program, there was the creation of an information portal in Russian for the inhabitants of the Donbas that would bring them the point of view of Kyiv: with the 
new law, the realization of such a website is certainly more complex. In his inaugural speech (when he also briefly expressed himself in Russian)

Before focusing on Zelensky's presidency, let's take a step back to give a general overview of the election process in Ukraine. First, following Article 92, the Constitution of Ukraine determines the organization and procedures of holding elections through a special law regulating the processes necessary for the elections of the President of Ukraine, named "On the election of the President of Ukraine". According to this Law, regular elections of the President of Ukraine are to be held on the last Sunday of March of the fifth year of office of the President of Ukraine currently in charge.

According to Article 17 of the Law of Ukraine "On Elections of the President of Ukraine", the Ukraine Central Election Commission announced the beginning of the election process for the 2019 Presidential election - to be held on March 31, 2019 - on December 31, $2018^{39}$.

The Verkhovna Rada of Ukraine on November 26, 2018, adopted Resolution No. 2631-VIII "On the Appointment of the Next Elections of the President of Ukraine", which appointed regular elections of the President of Ukraine on Sunday, March 31, 2019.

\begin{tabular}{|l|l|}
\hline Polling stations & 29,989 \\
\hline International official observers & 2,700 \\
\hline Media representatives & 1149 \\
\hline $\begin{array}{l}\text { Total election funds of candidates for the post } \\
\text { of President of Ukraine }\end{array}$ & UAH 1.728 billion \\
\hline Candidates for presidency & 92 \\
\hline People have been registered for voting & 29.456 .400 (1st tournament) \\
\hline
\end{tabular}

Table 2: 2019 Presidential election in numbers

In 2019 Presidential election have been used 29,989 polling stations, 28,653 of which ordinary and 1,235 special. At the same time in connection with the temporary occupation of part of the territory of Donetsk and Luhansk regions, only 2 out of 95 polling stations were prearranged in these elections.

To increase the transparency of the election process and the level of confidence of the international community for the results, 2019 Presidential elections were supervised by 2.700 international official observers, 215 from foreign countries, and 2.485 from international organizations. The Organization for Security and Co-operation in Europe (OSCE ODIHR), the European Network Election Observation Organizations (ENEMO) and the World Congress of Ukrainians (Світового Конгресу Українців) - were the

\footnotetext{
${ }^{39}$ See: Decree m. Kyiv December 27, 2018 n.253 “About the beginning of the election process for the next Presidential election on March 31, 2019 ips.ligazakon.net
} 
largest international Presidential observation mission elections in Ukraine. 1149 representatives from 192 media were accredited $^{40}$ to cover the event. To finance the election campaign, each candidate is compelled to create its own election fund, that needs to be formed in the manner established by the Law. The total size of election funds of the candidates for the post of President of Ukraine was more than UAH 1.728 billion, used by candidates to fund their election campaign. It is interesting to notice that the largest share in the total amount of expenses regarded the expenses related to the use of the media $(67.1 \% \text { or UAH } 1.16 \text { billion })^{41}$.

For the very first time in history, a record number of candidates submitted to the Presidency of Ukraine: 92 candidates expressed a desire to participate in this electoral race. Following the criteria demanded by the law ${ }^{42}$, the Central Election Commission registered only 44 candidates for the post of President of Ukraine (among which 24 nominated by political parties, and 20 selfnominated). 29.456.400 people had been registered for voting at the first tournament and 29.522.476 for the second.

The exclusive characteristic of these elections - due to the very high number of candidates, $44^{43}$ - is not surprising to those who know well the Ukrainian political dynamics: the reduction of the country's energy availability and reduced infrastructural potential, following the loss of the Donbas coal mines in 2014 - led to the multiplication of the oligarchic factions. In fact, in the past, the energy factions were more compacted while now appear as smaller and divided, and each of these groups is interested in bringing one of their people to the Presidential chair.

Among the candidates, only four were in a condition to win the Presidential election: Poroshenko, Zelensky, Tymoshenko, and Boyko. They were geographically distributed in this way: Petro Poroshenko obtained the majority in Ternopil and Lviv (Western part of the country); Yulia Tymoshenko in the Ivano-Frankivsk region (Western part of the country) and Yuriy Boiko in the Donetsk and Luhansk regions (Eastern part). The overall majority was achieved by Zelensky: according to the results released by the Central Electoral Commission, the actor Volodymyr Zelensky obtained 30.24\% of

\footnotetext{
40 See: List of the authorized media. www.cvk.gov.ua

${ }^{41}$ See: 2019 presidential election. www.pravda.com.ua

42 According to part two of Article 103 of the Constitution Ukraine and parts of Article 9.1 of the Law candidates must: be a citizen of Ukraine who has reached the age of thirty-five, has the right to vote, lives in Ukraine during the last ten years before the Election Day and speaks the state language.

43 Tadeusz, I., "Krzysztof Nieczypor. Ukraine’s Presidential elections”, OSW Report, Warsaw, 2018.
} 
the votes, followed by the outgoing President Petro Poroshenko with 15.95\%, Yulia Tymoshenko with 13.4\%, and Yuriy Boyko with 11.6\%.

\begin{tabular}{|c|c|c|}
\hline First-round 31.03.19 & Total & Total on the region \\
\hline Volodymyr Zelensky & $30,24 \%$ & Overall winner \\
\hline Petro Poroshenko & $15,95 \%$ & $\begin{array}{c}\text { Ternopil }-24.36 \% \\
\text { Lviv }-35.32 \%\end{array}$ \\
\hline Yulia Tymoshenko & $13,4 \%$ & $\begin{array}{c}\text { Ivano-Frankivsk }-22.51 \% \\
\text { Donetsk }-36.87 \% \\
\text { Luhansk }-43.96 \%\end{array}$ \\
\hline
\end{tabular}

Table 3. Source: elaborated from Ukraine Central Electoral Commission

In a deeply divided Ukraine, with a bent economy and an ongoing conflict, the theme of Russia is, of course, one of major importance on the political agenda of all candidates. From the uncompromising Poroshenko - who was not willing to deal with Moscow neither on the Donbas nor on the Crimea questions - to the 'reformist' Tymoshenko - who wanted to replace the Minsk process with the 'Budapest format' that would supplant Paris and Berlin with London and Washington -; last but not least was Zelensky who, with realism, claimed that the return of Crimea to Kyiv could only be talked about after "a change of power in Russia" while the Donbas negotiations should include "US and EU as witnesses". Before analyzing the Zelensky-Poroshenko ballot it is interesting to make a brief excursus on the highlights of the electoral programs running in this first round.

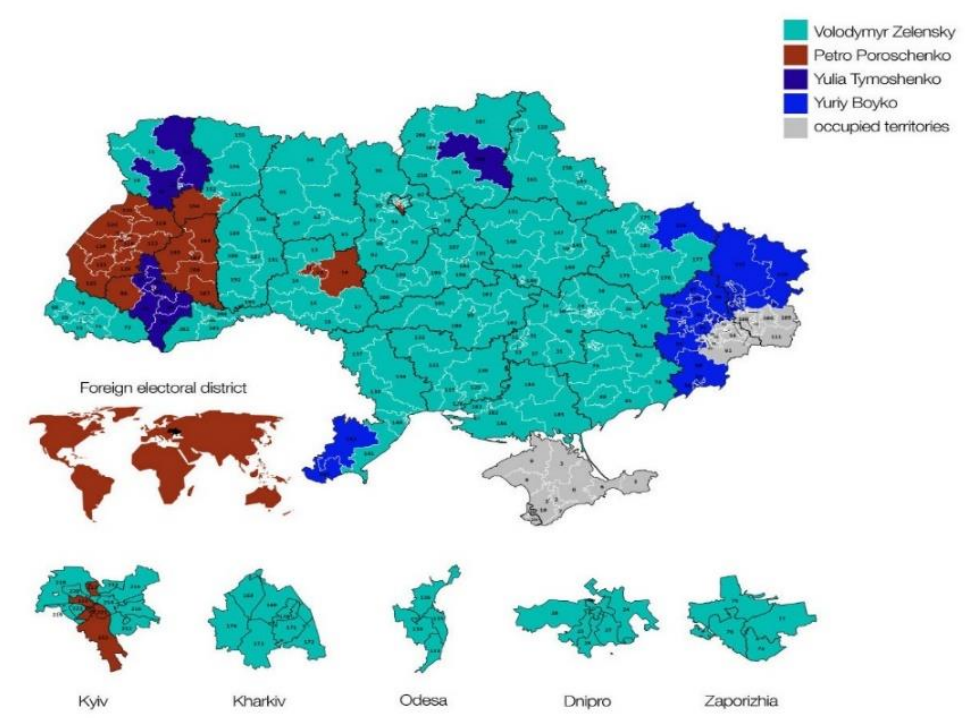

Figure 2. Source: elaborated from https:// en.wikipedia.org/wiki/2019 Ukrainian Presidential election 


\section{Volodymyr Zelensky}

Zelensky defined the resolution of the conflict in the eastern part of the country as priorities for the country. However, it is unlikely that the President would choose to put himself too clearly on the side of the Russian speakers in the revision of this legislation. On the other hand, the legislative choices in the linguistic field of this state are also the result of the profound and tragic forced Russification process carried out by the Tsars and then by Soviets. The strenuous research and protection of dignity and linguistic autonomy are part of the attempt to emancipate the country, even politically, from the eastern neighbor. If these measures were undoubtedly popular in Ukraine, they weren't enough to make Poroshenko win a new Presidential mandate. Even the strategy to discredit Zelensky as a "not sufficiently Ukrainian" candidate was not enough. Huge posters that appeared throughout the country during the election campaign showed Poroshenko's face as opposed to that of Russian President Vladimir Putin instead of that of the challenging candidate Zelensky suggesting to the Ukrainians that the choice to perform on the day of the ballot was among the interests of Ukraine (represented by Poroshenko) and those of Moscow (represented by Putin but also, indirectly, by Zelensky). In a Facebook post on April 9th, Poroshenko wrote:

(..) The number of Ukrainian experts and politicians who have run in defense of Putin's rights is a lot. Among them, unfortunately, the candidate of Zelensky. Putin is outlawed. He started a war against Ukraine. He annexed the Crimea. He is a murderer of thousands and thousands of Ukrainians. (...) The task of the advertising is to remind the country that under the conditions of these external challenges, a strong President and an experienced negotiator is needed. (...) Poroshenko's team don't consider Zelensky as an agent of Putin. We don't know. But we firmly believe that Putin dreams of a weak President who will allow the Kremlin to take Ukraine under control. In the end, Putin bimself said he would manage anyone as President of Ukraine except Poroshenko. (...)

The pompous electoral manifesto of Poroshenko ("Army! Language! Faith!") was therefore not sufficient to compensate for an evanescent political program. His program presented very few real proposals (development of the IT and tourism spheres, vague social assistance mainly regarding pension) and a hateful geopolitical proposal to at least half of the population (entrance in NATO in 2023). The President's team was well aware of the situation, so they set the fous of the electoral campaign on the three dogmas mentioned, valid for all seasons: an efficient and invincible army, a widely spread Ukrainian language, a completely national religious confession free from the influence of Moscow Patriarchate. The measures taken by Poroshenko to increase the electoral basin have not yielded the hoped results, apart from a slight increase in support in western Ukraine (mainly Russophobic and Catholic), where the State of War has been received more favourably than in the central regions and in the Eastern part of the country. 
Born in the east of Ukraine, speaking Russian as a first language, and despite being accused of having links with the controversial Ukrainian tycoon Igor Kolomoysky, Zelensky was able to win the majority of votes thanks to an electoral campaign that emphasized the national unity and social and economic change: the two areas in which Ukrainians expect concrete results from the new President. Before analyzing the voters' preferences at the Presidential elections, a focus on the election process of the Ukrainian President is considered necessary ${ }^{44}$.

\section{Petro Poroshenko}

During the last plenary session of the Verkhovna Rada ${ }^{45}$, held on September 20, Poroshenko officially announced his desire to carry on his presidency. He recognized the mistakes made during his presidency, while clearly outlining the guidelines characterizing his electoral campaign. A program that can be summarized with just three words, the same ones that appear in the campaign slogan: army (armija), language (mova), faith (vira). However, these three words are not just a simple slogan for the President's campaign, but the formula of the current Ukrainian identity: "The army defends our land, the language our heart, the church our soul", highlighted Porošenko. A formula coined to win over future voters since only the army can be considered as a responsibility of the head of state when language and faith are elements that go beyond the Constitution.

\subsection{The army defends the homeland.}

The defense of territorial sovereignty is currently a subject of fundamental importance in the country, and all the candidates were well aware of this Porošenko in the first place since from 2014 he has had to face many challenges in this regard. However, he did not hide his head in the sand, recognizing his shortcomings and finding the courage to apologize to the citizens for failing to put an end to this war. This move could be interpreted as a sign of humility or a tactic to win more votes during the campaign. Perhaps a mélange of both, although he reiterated the fact that the Ukrainian army has improved a lot in the last four years, both quantitatively and qualitatively, becoming more solid, compact, and -most importantly- deSovietized. The Ukrainian national identity (the pleonastic reason for his

\footnotetext{
${ }^{44}$ See: Law of Ukraine "On the election of the President of Ukraine" with amendments of 13.03.2014 https://cedem.org.ua/

45 See: Poroshenko delivered the annual message to the Verkhovna Rada, 20.09.2018. https://www.youtube.com
} 
speech) has taken over, especially among the younger part of the population, that are willing to fight for their homeland more than others ${ }^{46}$.

\subsection{The language takes care of our hearts}

The linguistic aspect is also of great interest, a crucial debate that involves all citizens, as already mentioned before. The process of linguistic "Ukrainization" of all media, from radio and television to cinema and publishing, has been strengthened and is slowly growing, but undoubtedly requires time and patience. "Finally, we defend, develop, and reaffirm the Ukrainian language, a component of the strength and success of our people. We will continue to take effective measures to consolidate the status of the Ukrainian language, strengthening it and spreading it in all spheres of public life" ${ }^{\prime 7}$.

\subsection{Faith protects our soul}

It is not surprising to see a marked reference to faith, or rather to religion. Freedom of the Church means spiritual freedom and tomos is synonymous with independence. The approval of the latter by the ecumenical council would thus prove to be a further act of proclamation of Ukrainian independence. Last April, Poroshenko had requested to the Patriarch Bartholomew the obtainment of the autocephaly of the Ukrainian Orthodox Church. Porošenko, in his political program, guaranteed that the state would respect the choice of those who decide to remain under the Russian Orthodox Church, but also promises total protection to the clergy and all the faithful belonging to the Ukrainian Orthodox Church of the Moscow Patriarchate who wants to enter the newborn Ukrainian autocephalous Church, which will become unique and independent.

In Poroshenko's political speech, the road to the European Union and NATO was the only one able to guarantee security and peace, as well as an improvement in living standards for the Ukrainian people, A political goal that becomes part of the constitution. However, Porošenko's strategy was not intended to be limited to EU membership alone, but to a profound Europeanization of the country, consolidating European values at 360 degrees, from democracy to equality, to respect for human rights. $\mathrm{He}$ declared himself confident that Ukraine was in possession of all the

\footnotetext{
46 Unian Information Agency (19.09.2018), "Poroshenko stated the need for legislative regulation of the status of the Ukrainian Language News Agency". https://www.unian.net

${ }^{47}$ Unian Information Agency (19.09.2018), "Poroshenko stated the need for legislative regulation of the status of the Ukrainian Language News Agency". https://www.unian.net
} 
characteristics for joining the European Union and the Alliance: "We are not only fighting for ourselves, but also for Europe, for democracy and freedom, for the 'West and its values'.

Another argument, although not sufficiently treated together with that of the precarious and fluctuating economic situation, was the fight against corruption. Anti-corruption organizations, which have seen significant financial investments, did not turn out to be successful. "Society is disappointed by the dynamics of anti-corruption struggle, and people's claims are absolutely justified", said Poroshenko. Constant issues were also the increasingly tense relations with Russia (repeatedly defined by the President as the "aggressor" or the "enemy").

With his three magic words (army, language, faith), Porošenko seemed to go back over the centuries, again promoting traits that were characteristic in the mid-nineteenth century, when nation-states were first being formed. Now similar slogans in Europe are perceived as an anachronism, something similar to the Russian imperial triad: "Autocracy, nationality, orthodoxy".

\section{Yulia Tymoshenko}

It's difficult to understand why a character with such a controversial past was still at the forefront of political affairs in the country. Few, in fact, imagined that Yulia could still have a voice in Ukrainian politics when, on 23 February 2014, presented herself in Independence Square and was greeted by many whistles. Tymoshenko, however, still participated in the elections and launched her electoral campaign with the slogan "the new course of Ukraine" demonstrating her chameleon-like qualities. Ukraine's prime minister, the global face of the Orange Revolution, famous as the "gas princess" because of her profitable activities leading a large company in the field of energy during the 90 s and imprisoned by two different presidents, Tymoshenko obtained the majority of the votes in the Ivano-Frankivsk region ${ }^{48}$ with a program based on five main points:

- peace and security policy - A new strategy for peace and security aimed at ending conflicts in Donbas and re-obtain Crimea with diplomatic measures and through a strengthened army. She proposed an alternative to the formula of the Minsk agreements, and she required compensation from Russia for all the suffered damages.

- the people's constitution - A new popular constitution with the abolition of the oligarchic system and the clans. It proposed a reduction of the number of deputies, from 450 to 350, and emphasized the importance of the referendum as a way through which citizens can express their opinion.

- new economic course - A new economic strategy based 1) on changing monetary policies to restore the confidence in the banking system, 2) on an energy

${ }^{48}$ See: Yulia Tymoshenko’s official website. http://old.kmu.gov.ua 
strategy, to create non-Russian gas import channels and reduce dependency from Moscow to enhance development and reduce internal tariffs, 3) on the agricultural sector, by proposing the introduction of a single tax per hectare and 4) on the tax system, by eliminating taxes that favour corruption and introducing a more efficient pension system.

- social policy - A new social doctrine based on the introduction of mandatory health insurance at the expense of employers and the European minimum wage to reach the salary received in Poland, now 3.5 times higher than the average Ukrainian one. This new plan was launched next to a program aimed at promoting culture throughout the country and abroad.

- youth policy - A new policy for young people based on a good level of education and taxes-cut to promote the hiring of graduated employees. Credit policies had also been proposed, to facilitate entrepreneurship and the obtainment of family allowances for young families.

Behind the slogan that guided her electoral campaign, Tymoshenko talked about a "new social contract" for the country, a massive constitutional reform and greater citizen participation in political life, while also supporting the Europeanist orientation. However, Tymoshenko insisted on the obsolescence of the Constitution, which guarantees - in her opinion - excessive powers to the President. Her proposal, therefore, appears simple and direct: to transform the political system from presidential to parliamentary, with a strong Prime Minister. There were also references to the war in Donbas and Crimea. It is precisely on those points that Julija Tymoshenko distinguished herself from the majority of other candidates: she openly spoke about peace and compromise, words that rarely resonate in the mouths of politicians in Ukraine. "I know how and with whom to negotiate, I know how to act to achieve peace", this was the message launched by the convention stage she organized in $\mathrm{Kyiv}^{49}$ to inaugurate her candidacy. Many ${ }^{50}$ saw Yulia as the ideal candidate for the Kremlin; others ${ }^{51}$, often abusing a term that came forcefully into the modern political vocabulary: populist. Pragmatic and opportunistic, she has already shown herself several times to be able to "come to terms with the devil" for her personal gain, in politics as well as in business. In Ukraine, too, there have been rumors of closeness between Julija Tymoshenko and Viktor Medvedčuk, the closest figure to Moscow in the country's political

\footnotetext{
${ }^{49}$ BBC Ukraine News (15.06.2018), Naked Torso, "Mistakes and Loud Quotes from Tymoshenko's Forum", www.bbc.com

${ }^{50}$ Niland, P. (20/06/2018), “Tymoshenko, again?” kyivpost.com

51 Volodymyr Groysman (14.02.2017), "Groysman calls Tymoshenko "mother" of popu-

lism, corruption in Ukraine Information Agency”, Unian Information Agency.

www.unian.info
} 
scene $^{52}$. On the other hand, however, it is undeniable that, with her rhetoric, Tymoshenko was still capable of attracting such a large number of votes, symbolically representing one of the greatest failures of the Poroshenko administration. The former revolutionary heroine was aiming at gaining support among the $83.7 \%{ }^{53}$ of Ukrainians who declared that they were unhappy with the direction taken by the country, pointing the finger at Petro Porošenko's four-year presidency. Not surprisingly, the media close to the President (like 5 Kanal) campaigned against Tymoshenko by supporting other opposition candidates, including Juriy Bojko, a former ally of Janukovyč. The Presidential administration's calculation was clear: it would have been better to arrive, possibly, in the second round against a character like Bojko (considered pro-Russian) than against Tymoshenko.

But Tymoshenko could also count on a complex network of organizations parallel to her party which extends throughout the country. It is not just a question of affiliated civic organizations, but also youth organizations. An example is Batkivschina Moloda ${ }^{54}$, which not only organizes summer camps but also conducts the political activity in schools and universities. Young people represent a discrete electoral basin for Julija Tymoshenko. Generally and rather paradoxically, Tymoshenko was not only the perfect candidate for those who are dissatisfied with the current political course of the country, but also with those who see war as one of the main reasons for the economic crisis and the difficulties of a substantial band of the population. Those who would have wanted, in other words, the end of the conflict starting from less intransigent positions than those of the Poroshenko leadership not so much willing to compromise with the Kremlin.

\section{Yuriy Boyko}

One of the extremist names of this electoral race was the one of pro-Russian Yuriy Boyko from 'Opposition Platform-For Life', who won the majority in Donetsk - a city in Eastern Ukraine, capital of the unrecognized Donetsk People's Republic - and Luhansk, an administrative centre of the unrecognized nation Luhansk People's Republic. Hosting a large percentage of people of Russian ethnicity, these two regions suffered and are still suffering the division of the country. After the Ukrainian revolution in 2014, the two republics self-proclaimed their independence from Ukraine to be

\footnotetext{
52 Taras Kuzio (19.04.2018), “Yulia Tymoshenko's Controversial "Middle-Man", New Eastern Europe. neweasterneurope.eu

${ }^{53}$ See: Social and political attitudes of the residents of Ukraine: June 2018, Kyiv International Institute of Sociology, 25.06.2018. www.kiis.com

${ }^{54}$ See: Batkivschina Moloda official website, https://ba.org.ua/
} 
integrated with Russia, even if Kyiv never recognized it. This annexation stopped about the $12 \%$ of eligible voters from taking parts in the 2019 Presidential elections. This context would explain to the international opinion the desire to vote for the pro-Russian Boyko. During his campaign, Boyko stressed that his priorities as a President were two: to stop the bloody opposition in eastern Ukraine and to stop poverty. He is well-known for his firm pro-Russian position, claiming that one of the key points of this electoral program would be 'direct negotiations with Russia', which he believes would help in bringing an end to the ongoing Donbas conflict. Another important provision of his program was to cancel the present healthcare reform and to introduce an accessible and high-quality medical service provided by the government, along with the revision of the pension reform.

\begin{tabular}{|c|c|c|c|c|}
\hline Candidates & Party & $\begin{array}{c}\text { Previous } \\
\text { employment }\end{array}$ & $\begin{array}{l}\text { Campaign } \\
\text { announced }\end{array}$ & $\begin{array}{c}\text { Main points of } \\
\text { his/her campaign }\end{array}$ \\
\hline $\begin{array}{l}\text { Volodymyr } \\
\text { Zelensky }\end{array}$ & $\begin{array}{l}\text { Servant of the } \\
\text { People }\end{array}$ & $\begin{array}{c}\text { Showman, } \\
\text { screenwriter, actor, } \\
\text { and art-director of } \\
\text { Kvartal } 95\end{array}$ & $\begin{array}{l}31 \text { December } \\
\text { 2018. - live on } \\
\text { a TV show }\end{array}$ & $\begin{array}{l}\text { - War against corruption } \\
\text { and oligarchy } \\
\text { - Connect with citizens } \\
\text { through a horizontal } \\
\text { communication } \\
\text { approach } \\
\text {-Re-annexation of } \\
\text { Crimea and end of } \\
\text { Donbas war }\end{array}$ \\
\hline $\begin{array}{c}\text { Petro } \\
\text { Poroshenko }\end{array}$ & $\begin{array}{l}\text { Independent } \\
\text { (Petro } \\
\text { Poroshenko } \\
\text { Bloc } \\
\text { "Solidarity") }\end{array}$ & $\begin{array}{l}\text { Current President of } \\
\text { Ukraine, businessman }\end{array}$ & $\begin{array}{l}29 \text { January } \\
2019 .\end{array}$ & $\begin{array}{l}\text { - Enhanced army } \\
\text {-Territorial sovereignty } \\
\text {-Defense of the } \\
\text { Ukrainian language } \\
\text {-The autocephaly of the } \\
\text { Ukrainian Orthodox } \\
\text { Church }\end{array}$ \\
\hline $\begin{array}{c}\text { Yulia } \\
\text { Tymoshenko }\end{array}$ & Fatherland & $\begin{array}{l}\text { People's Deputy of } \\
\text { Ukraine and former } \\
\text { Prime Minister of } \\
\text { Ukraine (2005; } \\
\text { 2007-2010) }\end{array}$ & 20 June 2018 & $\begin{array}{l}\text {-Peace and compromise } \\
\text { for Donbass } \\
\text {-Normandy format } \\
\text { proposal } \\
\text {-Decrease the number } \\
\text { of deputies } \\
\text {-New economic course } \\
\text {-Augmented salary } \\
\text {-New policies addressing } \\
\text { young citizens }\end{array}$ \\
\hline Yuriy Boyko & $\begin{array}{l}\text { Opposition } \\
\text { Platform } \\
\text { — For Life } \\
\text { alliance. }\end{array}$ & $\begin{array}{l}\text { People's Deputy of } \\
\text { Ukraine and ex- } \\
\text { Minister of Fuel and } \\
\text { Energy of Ukraine }\end{array}$ & $\begin{array}{l}17 \text { November } \\
2018\end{array}$ & $\begin{array}{l}\text { - Direct negotiation } \\
\text { with Russia for the } \\
\text { Donbas struggle. } \\
\text {-Medical reform } \\
\text {-Revision of the } \\
\text { pension reform }\end{array}$ \\
\hline
\end{tabular}

Table 4. Source: elaborated from Wikipedia -

bttps:// en.wikipedia.org/wiki/2019 Ukrainian Presidential election 


\section{The ballot}

The Presidential elections of 2019 represented the first time -after the "democratic revolutions" of 1990, 2004, and 2013-2014- in which there was a substantial uncertainty on who would have gone to the ballot. Poroshenko and Zelensky clashed in the second tournament on April 21, as neither of them obtained $50 \%$ of the votes in the first round. After the public debate, organized by Zelensky at the Kyiv Olympic stadium (see chapter 3), the comedian won the elections with an overwhelming majority of $73 \%$ (see ANNEX 2 - Voters' preferences in each region). This has been considered the vote of revenge with a credible and structured political program on the real needs of his electorate.

\begin{tabular}{|l|l|l|}
\hline Second round 21.04.19 & \multicolumn{2}{|l|}{} \\
\hline & $\%$ votes & Total number of votes \\
\hline Zelensky Vladimir & 73 & 13541528 \\
\hline Poroshenko Petro & 24 & 4522450 \\
\hline \multicolumn{2}{|l|}{ Total number of voters 18.491.837 (Spoiled 427.859) } \\
\hline
\end{tabular}

Table 5. Source: elaboration from wnw.cvk.gov.na

A clear defeat for Poroshenko: the gap between the two candidates is the largest ever recorded in Ukraine and the worst result for the candidate defeated in the second round. What the Presidential administration had defined as "the puppet [of the oligarch] Kolomoisky" or the "candidate of the Kremlin" won in all the regions of the country (except for Galicia). This, with all due caution, largely confirmed the results of the first round and showed how the Ukrainian society was presenting itself as less divided than it was believed to that point. The protest vote intercepted by Zelensky, thus, not only did represent the rejection of the majority of Ukrainians of the economic policy of Poroshenko and his government but also of his ultra-nationalist cultural policy, especially in the last phase of the electoral campaign.

The great margin between the two candidates could also have meant the end of Poroshenko's political career, on the scene since the distant 1998. Although in his press conference after the vote, the outgoing president said he was still ready to fight for the next parliamentary elections and the presidency in five years, it remains difficult to foresee him as a still politically valid figure. Not surprisingly, many, especially among the ruling class at the regional level, have already begun to abandon the scene, seeking new accommodation and contacts in the winner's lines. Anyway, Poroshenko accepted the final result with no tensions. 


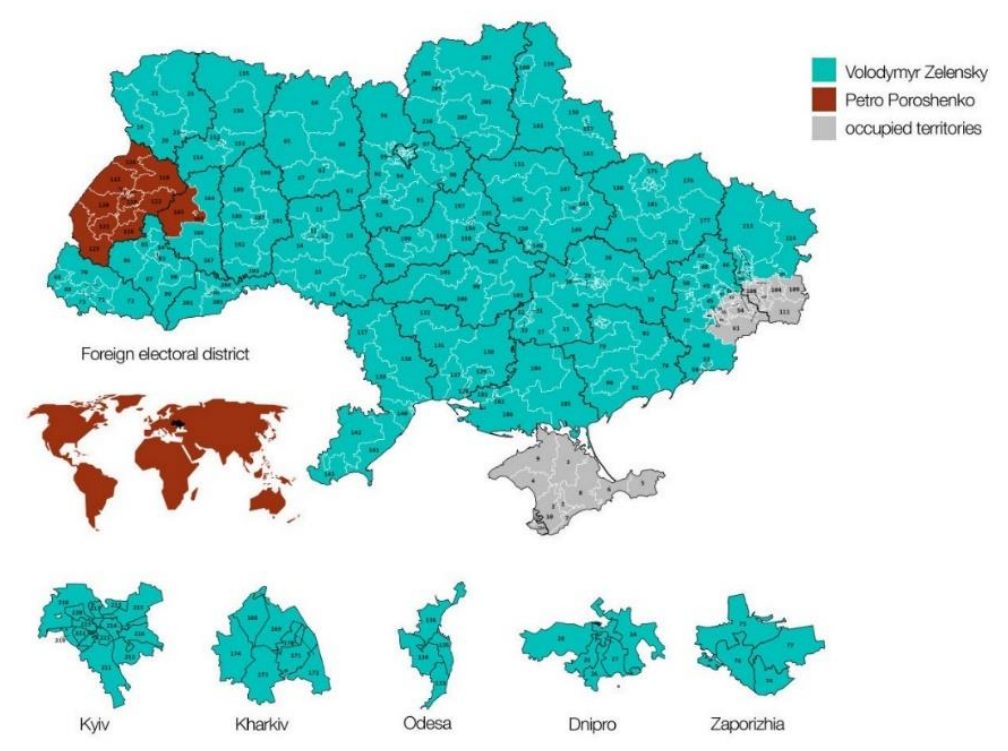

Figure 3. Source: elaborated from

https://en.wikipedia.org/wiki/2019_Ukrainian_Presidential_election

\section{Reactions to the vote in Europe and Russia}

Positive reactions came from European leaders about the outcome of the discussed Ukrainian Presidential elections. The former High Representative for Foreign and Security Policy of the European Union, Federica Mogherini, had already declared before the elections that the EU would continue to work with Ukraine "regardless of the result". The election of Zelensky is indeed destined to have significant consequences both for the EU and for the single Member States. First of all, there will be a continuation of the economic and political reforms advocated by the EU and the IMF. Analyst Serhiy Fursa noted $^{55}$ that markets generally perceive Zelensky positively, since the comedian does not appear to pose a threat to the progress of reforms, to which are openly opposed both Yulia Tymoshenko and Poroshenko. However, other analysts ${ }^{56}$ see Zelensky as a "potential danger for the reforms due to his anti-establishment rhetoric and his violent criticism of the IMF, the EU, and what he called a "Europeanist elite", accused of orchestrating painful reforms bringing limited benefits and high social and economic costs.

\footnotetext{
${ }^{55}$ See: "Zelensky's attitude to IMF program will be main marker for markets - expert", (01/04/2019), INTERFAX. en.interfax.com.ua

${ }^{56}$ Korosteleva E. (17.04.2019), “A Comedian, a President, and a Prime Minister: The 2019 Presidential election in Ukraine", ISPI. www.dahrendorf-forum.eu
} 
The success of the Zelensky reform program is a test for the credibility of the Eastern Partnership, the EU regional integration plan for its "eastern neighbours", and the implementation of the Association Agreement with the EU. Becoming an actual EU member is the desire of large shares of the Ukrainian elites and civil society, and these elections were the first in the history of Ukraine in which the candidates did not insist on the dichotomy "integration with the Russia vs integration with the West". Currently, the Euro-Atlantic integration ${ }^{57}$ is an objective explicitly mentioned by the Ukrainian Constitution and has been married by all three major candidates in these elections. However, this aim is far from undisputed: according to a survey by the Rating group, support for European integration is not evenly distributed throughout the country, passing from an acceptance exceeding $80 \%$ in the regions adjacent to Europe, to around $30 \%$ in the regions of Donetsk, Luhansk, and Odesa (data that can also explain the different geographic distribution of the vote). Moreover, an actual offer of a European membership has never been officially brought to the negotiation table between Kyiv and Brussels, not to mention the fact that the so-called "enlargement process fatigue", together with the advancement of populist and euro-sceptical sentiments and movements in many European countries, make this perspective less and less realistic in the medium term. Already in 2016, the Association Agreement with Ukraine was rejected by Dutch voters in a referendum ${ }^{58}$ and to save what was agreed, European leaders had to specify that Ukraine had been promised neither the membership in the EU nor military aid in case of a military invasion. Therefore, the real challenge of the EU will be to continue to support a reform process in Ukraine, with a more sceptical President than Poroshenko and without the powerful incentive of the prospect of future membership.

During the twenty-first EU-Ukraine summit held in Kyiv on 8 July, the European Council President Donald Tusk and the chief of the Euopean Commission Jean-Claude Juncker, along with Volodymyr Zelensky reiterated the strength of political and economic ties between the EU and Ukraine by

\footnotetext{
${ }^{57}$ Zarembo K. (27.03.2019), “The Domestic and Regional Stakes of Ukraine's Elections”, ISPI. www.ispionline.it

58 See: "Dutch referendum voters overwhelmingly reject closer EU links to Ukraine", The Guardian, (07/04/2016). www.theguardian.com
} 
discussing the implementation of the association agreement and the way forward in EU-Ukraine relations.

"The European Union's partnership with Ukraine is one of mutual solidarity and friendship. It is also one that is flourishing: we have achieved more progress together in the last five years than we did in the two decades before. Ukraine has taken up ambitious reform commitments. The EU, in turn, has provided Ukraine with unprecedented support, from financial and expert support to autonomous trade measures, and almost 3 million visafree visits to the EU for Ukrainian citizens to date. This, alongside continued unity on sanctions, shows the EU's commitment to Ukraine - one that remains unwavering", observed President Donald Tusk after the Summit.

\section{I st EU-Ukraine Summit: moving forward together in solidarity. \\ MAIN DECLARATIONS}

The EU provides additional $€ 119$ million for accountable and efficient governance in Ukraine and to step up its support to the Sea of Azov region.

The EU provides additional support to decentralisation, fight against corruption, empowerment of civil society and accountable and efficient governance in Ukraine.

The EU has been supporting projects aimed at mine risk mitigation as well as for psycho-social support.

The European Union reaffirmed its unwavering support for Ukraine's independence, sovereignty and territorial integrity. The EU continues to implement its non-recognition policy for the illegal annexation of Crimea and Sevastopol by the Russian Federation, including through restrictive measures.

Elaborated by the author from

https://ec.europa.eu/commission/presscorner/detail/en/IP_19_3810

In conclusion, if in 2013 the Association Agreement with the European Union and the Customs Union with Russia were two rival projects for Ukrainians, in 2019 support for the EU is overwhelming among the population $50 \%$ of Ukrainians support the country's integration into the EU, while only $9 \%$ are in favour of the Customs Union. However, the support for the EU is petty unevenly spread across the, country, spanning from over $80 \%$ of western oblasts to about $30 \%$ of the Donetsk, Luhansk and Odesa oblasts. At that point, the continued EU engagement with Ukraine was essential to enable reforms under the EU-Ukraine Association Agreement to be enforced ${ }^{59}$, as is

\footnotetext{
${ }^{59}$ See: EU-Ukraine relations - factsheet. europa.eu
} 
the continuation of the EU's support for the inviolability of borders and international legislation, thereby delivering a firm signal to Russia.

\subsection{Russia}

As for Russia, at the election of Zelensky, the spokesman of Russian President Dmitri Peskov stated that "it is premature to talk about the possibilities of cooperation with the new Ukrainian administration". In reality, the rise of Volodymyr Zelensky to power seems to be taking the first steps towards resolving the Ukrainian crisis. This is also the direction of the two phone calls of Zelensky to Vladimir Putin - 11 July and 7 August $^{60}$ to discuss a resolution to the conflict plaguing the south-east part of the country and to intensify peace negotiations in the Donbas, following the Normandy format, between Ukraine and Russia, flanked by Paris and Berlin that both expressed total support in the people of Emmanuel Macron and Angela Merkel. Regarding the relations with Moscow, Zelensky said he was a supporter of the Minsk Process, primarily to "put out the fire and bring our boys back home" (referring to the sailors arrested in the Azov sea). Concerning the Donbas situation, he seemed convinced that "a huge information war", supported by the Ukrainian media, will favour an end to hostilities, while in Crimea the objective is clear: the return of the peninsula to Kyiv, conditioned by a change in the strategy of power of the Kremlin and, above all, from a desirable and decisive US support ${ }^{61}$. The dialogue with Moscow and the proposals for resolving the tragic Eastern question have fuelled the criticism from his rivals, who have accused him of being pro-Russian and a puppet of the oligarch Ihor Kolomojskij.

Despite this, Russian-Ukrainian relations are still tense to all degrees, despite the fact that Ukrainians appear to differentiate the Russian state from the Russian people: according to a survey conducted by the International Institute of Sociology in Kiev, 63\% of Ukrainians consider Russia to be an aggressor against Ukraine, but at the same time $57 \%$ of Ukrainians maintain a positive

\footnotetext{
${ }^{60}$ A phone call between the two leaders on August 7 on the wave of the crisis that broke out on the previous day after the killing of four Ukrainian soldiers in the Donbass would lead the leaders to a face-to-face direct confrontation.

${ }^{61}$ See: Zelensky calls US for tightening sanctions against Russia, (20.05.2019), President of Ukraine Official website. www.president.gov.ua
} 
outlook towards the Russian people ${ }^{62}$. How these two opposing trends can coexist lies in the fact that Ukrainians separate the Russian people from the Russian administration: the same survey shows that while $77 \%$ of Ukrainians have a favourable opinion of the Russian people, only 13\% of Ukrainians share the same sentiment towards the Russian government (see table below). Some of these good attitudes towards their neighbours could be explained by family and economic ties that exist between some Ukrainians and Russians, especially in eastern and southern Ukraine. At the same time, Russian perceptions with regard to Ukraine are considerably more negative, accounting for only one third of Russian citizens (34\%) declaring positive feelings and stances towards Ukrainians. Regarding the conflict resolution measures, Ukrainian public opinion is strongly divided. The opinions diverge from those in favour of the Budapest format (which allegedly includes the involvement of the United Kingdom, the United States, France, Russia and China in the negotiation format; with about $20 \%$ of Ukrainians being in favour) to those who seek to adopt the Minsk format; and others are arguing in favour of bilateral negotiations with Vladimir Putin, including the total abandonment of the occupied territories - each option is supported by about one in ten Ukrainians ${ }^{63}$.

\footnotetext{
${ }^{62}$ See: "Attitude of the population of Ukraine towards Russia and of the population of Russia towards Ukraine, September 2019”., Kyiv International Institute of Sociology, 15.10.2019. www.kiis.com.ua

${ }^{63}$ BAKER, P. (29/10/2019), “Trump Cancels Meeting With Putin, Citing Naval Clash Between Russia and Ukraine", The New York Times. www.nytimes.com
} 


\begin{tabular}{|c|c|c|c|}
\hline$\%$ & $\begin{array}{c}\text { \% of a positive } \\
\text { attitude toward } \\
\text { Russia as a } \\
\text { country }\end{array}$ & $\begin{array}{c}\text { \% of a positive } \\
\text { attitude toward } \\
\text { Russian lead- } \\
\text { ership }\end{array}$ & $\begin{array}{c}\text { \% of a positive } \\
\text { attitude toward } \\
\text { Russian popu- } \\
\text { lation }\end{array}$ \\
\hline west & 41 & 4 & 71 \\
\hline east & 75 & 34 & 87 \\
\hline south & 70 & 14 & 85 \\
\hline centre & 51 & 11 & 70 \\
\hline
\end{tabular}

Table 6. Source: elaboration from www.kiiis.com.na

\section{Conclusion}

In the end, the comedian Volodimir Zelenski won the Ukrainian presidential election by a large majority in 2019 and defeated what we can call the veteran Petro Poroshenko, who was quick to acknowledge his defeat, but said that he will not abandon politics, for Poroshenko Zelenski is without political experience and will face a strong opposition. Zelenski, on the other hand, has promised that his "number one" priority in office will be to end the war between the Ukrainian army and pro-Russian militias in Donbas.History does not change: the main challenge remains the confrontation with Putin's Russia. On September 7, 2019, Russia and Ukraine moved closer together under the new President Zelensky, making the first prisoner exchange since the war broke out in eastern Ukraine today. Both governments described this event as a "first step" towards the normalization of relations. The process began to be facilitated on July 11 by the first telephone conversation between Russian and Ukrainian presidents Vladimir Putin and Vladimir Zelenski. But another call was needed on August 7 to give a push to the exchange. This seems to be the new path. On the other hand, relations with Trump suddenly became difficult because of the scandal of the American President's interference in Ukrainian elections. Here, too, history is repeating itself, after all, it seems like a return to the Cold War.

In December 2019 Putin and Zelenski met in Paris in an attempt to find a solution to the Ukrainian war. Too many people in Europe have already forgotten about that war since it remained calm for several months, but it is far from over. The war has been going on for six years and has caused around 
13,000 deaths. The origin of the conflict is the fact that in the Donbass region, located in the east of Ukraine and on the border with Russia, pro-Russian rebels revolted against the government in Kiev and gained control of that territory with the help of Russia, and this must not be forgotten. The meeting was also attended by Angela Merkel and Emmanuel Macron. France and Germany had participated in the so-called Minsk Agreements in order to reach a settlement, but so far they have had no results. Putin is strengthened by talking only about Donbass, but not about the Crimea, which he does not intend to give back. Nothing seems to have changed except that Ukraine wants peace at all costs.

Yet in March 2020, just nine months after taking over the Ukrainian presidency, Vladimir Zelenski radically reorganizes the government with a new prime minister and eleven new faces, as he must already regain the confidence of the Ukrainians, he declares that "we need new leaders and new hearts," announcing yet another reform and a new crisis of consensus. According to Zelensky "when the government forgets its promises, it stops listening to people and seeing the need for change". Zelenski's political honeymoon with the Ukrainian people is now over.

The love story fades away in the face of the government's difficulties. The latest polls indicate a gradual loss of confidence of the Ukrainians in Zelenski. According to a survey published in February by the Centre for Social Surveillance, his popularity index has dropped to 49.4\%. The Covid 19 coronavirus crisis only deepened the crisis and there seems to be a very close link between pandemic and debt, since March 18 the whole country has been closed, GDP will fall and inflation will rise. The country is stuck, politics and economy are not helping help the new president, unable to react.

The Soviet Union is a long way away, Ukraine remains a very delicate point within the fragile international chessboard. It has tried to look to the European Union, but it could not or did not really want to help it, after all that is just a country that is no longer there, a great post-Soviet and post-Cold War laboratory afflicted by prevailing ostalgia, but eager to see a glimmer of light that cannot be the usual east-west confrontation to which is added the drastic Chinese appetite.

\section{References}

AA.VV. (1987), Cronologia universale, Rizzoli, Milano. AA.VV. (1990), Cronologia universale, UTET, Torino.

Armstrong J. A., Ukrainian Nationalism (3d ed. 1989), New York. 
Berton-Hogge R., Crosnier M., coordinato da (1995), Ukraine, Biélorussie, Trois Etats en construction, Les Etudes de la documentation française, Parigi. Berton-Hogge R., Crosnier M., a cura di (2000), Les pays de la CEI, Les Etudes de la documentation française, Parigi

Boffa G. (1979), Storia dell'Unione Sovietica, Mondatori, Milano.

Bogdan H. (1991), Storia dei paesi dell'Est, SEI, Torino.

Camera A. - Fabietti R. (1970), Storia. Dal 1848 ai giorni nostri, Vol. I, II, III, Zanichelli, Bologna.

Carr E.H. (1969), Storia della rivoluzione sovietica, Einaudi, Torino.

Chiesa G., Medvedev R. (1989), La rivoluzione di Gorbaciov. Cronaca della perestrojka, Garzanti, Milano.

Conte F. (1991) Gli slavi. Le civiltà dell'Europa centrale ed orientale, Einaudi, Torino.

Duby G. (1992), Atlante storico. La storia del mondo in 317 carte, S.E.I., Torino.

Drweski, a cura di (1999), L’Ukraine, un état indépendant en chantier, La Nouvelle Alternative $n^{\circ} 1$, Parigi.

Duroselle J.B. (1972), Storia Diplomatica dal 1919 al 1970, Edizioni dell'Ateneo, Roma, 1972.

Egorov I.(1994), Election Results and Prospects for Reform in Ukraine, PSBF Briefing, The Royal Institute of International Affairs, Russian and CIS Programme, $\mathrm{n}^{\circ} 1$.

Fedor H., a cura di (1993), Belarus and Moldova, Country studies, Federal Research, Division, Library of Congress, Washington.

Ferro M., a cura di, in collaborazione con Mandrillon M. (1993), L'état de toutes les Russies. Les états et le nations de l'ex URSS, La Découverte, Parigi. Figus A. (2002), Le società postsovietiche: Moldova, Mattioli 1885, Fidenza.

Gitermann V. (1973) Storia della Russia, La Nuova Italia, Firenze.

Kahn M. (1994), L'Ukraine deux ans après l'indépendance Le Courrier des pays de l'Est n 338 , La documentation française, Parigi.

Kappeler A. (1997), Petite histoire de l'Ukraine, Institut d'études slaves, coll. Irenise, Parigi.

Keesing's Record of World Events, Elections today, vol.6, 4, 1997, 1998, 1999, 2000, 2001.

King C (1995), Post-Soviet Moldova: a Borderland in Transition, The Royal Institute of International Affairs, Londra.

Kuzio T. (1998), Contemporary Ukraine, Dynamics of Post Soviet Transformation, Sahrpe, Londra.

Kuzio T. (1998), Ukraine. State and Nation Building, Routledge, Londra. 
Langer W.L., a cura di (-1974), Enciclopedia della storia universale, Sansoni, Firenze.

Le Courrier des pays de l'Est no 373 (numero speciale) (1995), Douze nouveaux états indépendants issus de l'URSS : la CEI, La documentation française, Parigi.

Jean C. (1995), Geopolitica, Laterza, Roma, Bari.

Jean C. (2002), 11 settembre attacco alla Russia, in Limes 1-2002.

Petracchi G. (1982), La Russia rivoluzionaria nella politica italiana 1917/25, Laterza, Roma-Bari, pp.43-55

Rjasanovskij N.V. (1965), Storia della Russia, Garzanti, Milano.

Rosato A. (2002), Sull'Ucraina, divisa si allunga l'ombra di Mosca, in Limes 42002.

Rudnytsky I. L. (1988), Essays in Modern Ukrainian History, Kiev.

Saitta A. (1988), Il cammino umano, Calderoni, Bologna.

Subtelny O. (1988), Ukraine: a History; Kiev.

Szporluk R. (1979), Ukraine: A Short History; Kiev.

Touscoz J. (1989), Atlas Géostratégique, Larousse, Parigi.

Unruluy Child (1994), A survey of Ukraine, The Economist, Londra.

Waldenberg M. (1994), Le questioni nazionali nell'Europa centro-orientale, Il

Saggiatore, Milano.

\section{Atlases, Dictionaries, Encyclopedias, Journals.}

Atlante storico Garzanti (2000), Redazioni Garzanti, Milano.

Conflitto Transnistria. Quali soluzioni per un problema europeo. (2001), ISIG

Magazine, $\mathrm{n}^{\circ}$ 2/3, Gorizia.

Cronologia della storia universale (1990), Garzanti, Milano.

Dizionario Enciclopedico di storia (1994), Mondadori, Milano.

Enciclopedia della Storia Universale (1996), Istituto Geografico De Agostini, Novara.

Enciclopedia Geografica Garzanti(2000), Garzanti, Milano.

Il Nuovo Atlante Storico Garzanti. Cronologia della storia universale (1997), Garzanti, Milano.

Il Nuovo Atlante Storico Zanichelli (1995), Zanichelli, Bologna.

L'état du monde (edizioni dal 1995 al 2002), Editions La Découverte \& Syros, Parigi

Le Maxidico (2001), Editions de la Connaissance, Parigi.

Sellier J. (1998), Atlas des peuples d'Europe centrale, La Découverte, Parigi. Stato del mondo 2003, Hoepli, Milano, traduz. de "L'état du monde 2003", Editions La Découverte \& Syros, Parigi. 


\author{
Web References \\ search.ligazakon.ua \\ zakon.rada.gov.ua \\ cedem.org.ua \\ ips.ligazakon.net \\ www.cvk.gov.ua \\ www.pravda.com.ua \\ www.unian.net \\ old.kmu.gov.ua \\ www.bbc.com \\ kyivpost.com \\ neweasterneurope.eu \\ www.kiis.com \\ ba.org.ue \\ en.interfax.com.ua \\ www.dahrendorf-forum.eu \\ www.ispionline.it \\ www.theguardian.com \\ europa.eu \\ www.president.gov.ua \\ www.nytimes.com
}

